\title{
Thoracic manifestations of segmental neurofibromatosis
}

\author{
Nader Chebib, ${ }^{1}$ Patrick Combemale, ${ }^{2}$ Denis Jullien, ${ }^{3}$ Vincent Cottin ${ }^{4}$
}

'Department of Pneumology, Hospices Civils de Lyon, National Reference Center for Rare Pulmonary Diseases, Lyon, France

2Department of

Oncodermatology, Centre Leon Berard, Lyon, Rhône-Alpes, France

${ }^{3}$ Department of Dermatology, Hôpital Edouard Herriot, Lyon, France

${ }^{4}$ Department of Pneumology, Hospices Civils de Lyon, National Reference Center for Rare Pulmonary Diseases, Lyon, France

\section{Correspondence to}

Professor Vincent Cottin, vincent.cottin@chu-lyon.fr

Accepted 2 September 2017

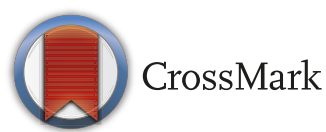

To cite: Chebib $\mathrm{N}$ Combemale $P$, Jullien $D$, et al. BMJ Case Rep Published Online First: [please include Day Month Year]. doi:10.1136/bcr-2017221253

\section{DESCRIPTION}

A non-smoking 57-year-old female presented with long-standing mild dyspnea and dry cough. Her medical history was remarkable for a subcutaneous right cervical nodule which corresponded pathologically to a neurofibroma. There were no other signs for type 1 neurofibromatosis as she had no family history of neurofibromatosis, no "café au lait» macules, no axillary or groin freckling, no plexiform neurofibroma, no cutaneous/subcutaneous neurofibroma and no Lisch nodules. Genetic testing for the Neurofibromin 1 (NF1) gene mutations was negative. MRI of the brain, spine and pelvis was normal, except for the right cervical neurofibroma measuring $4.5 \mathrm{~cm}$ in greatest diameter. Pulmonary function tests showed no obstructive or restrictive pattern. The chest radiograph demonstrated enlargement of the upper mediastinum with bilateral non-cavitating lobulated opacities (figure 1). Thoracic CT scan showed multiple bilateral round and non-compressive nodules and masses in the superior, anterior and posterior mediastinum, along with mediastinal lymphadenopathies (figure 2). These lesions predominated in the upper zones. Because the patient had mild symptoms, an invasive procedure to have pathological proof of the thoracic lesions was initially delayed. Such procedure was not necessary during the 10 -year follow-up

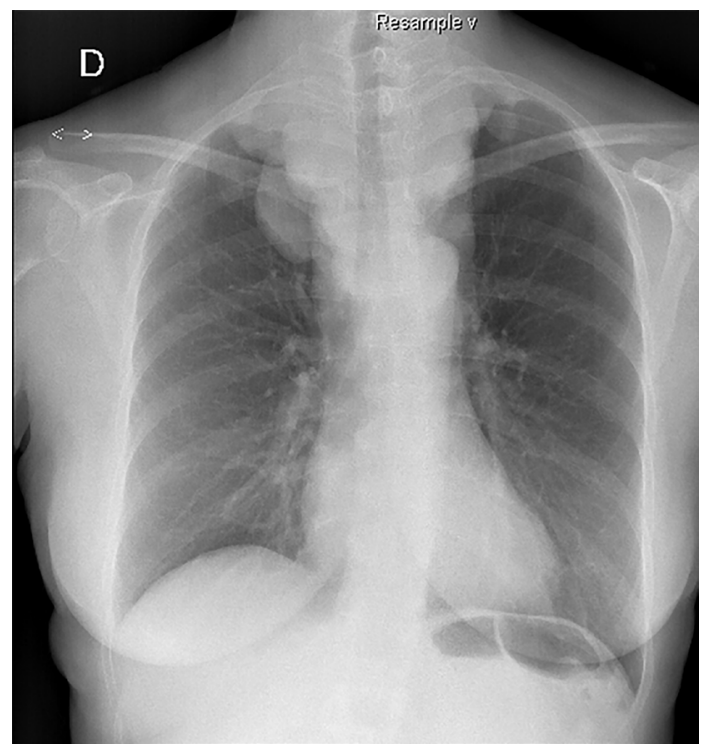

Figure 1 Chest radiograph showing enlargement of the upper mediastinum and numerous well-defined lobulated opacities.

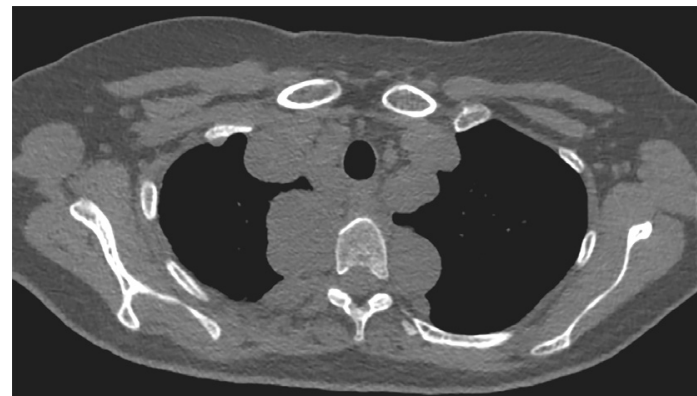

Figure 2 Thoracic $\mathrm{CT}$ showing bilateral mediastinal round nodules and masses, as well as mediastinal lymphadenopathies, corresponding to mediastinal neurofibromatosis.

because the lesions did not progress and the symptoms remained stable.

Neurofibromatosis is a group of genetic diseases characterised by the development of benign and malignant tumours of the central and peripheral nervous system, as well as characteristic cutaneous lesions. ${ }^{1}$ Mutations in the NF1 gene are found in 85\%-95\% of cases with neurofibromatosis type 1 . Thoracic involvement is rare and includes thin-walled cysts, reticular lesions, ground glass opacities, pulmonary nodules and mediastinal masses, as well as subcutaneous nodules of the chest wall. ${ }^{2} 3$ The radiological thoracic lesions observed in our patient and their stability over several years are suggestive of non-NF1 segmental neurofibromatosis. A pathological confirmation by biopsy was not sought because symptoms were limited, with

Learning points

- Neurofibromatosis type 1 is a genetic disease caused mainly by mutations in the Neurofibromin 1 (NF1) gene.

- Characteristic clinical features include cutaneous lesions ("café au lait» macules, axillary or groin freckling, cutaneous/ subcutaneous neurofibromas), as well as benign or malignant tumours of the central and peripheral nervous system. However, limited or segmental forms of NF1 can also be found.

- Thoracic involvement is rare and includes thin-walled cysts, reticular lesions, ground glass opacities, pulmonary nodules, mediastinal masses and subcutaneous nodules of the chest wall. 
cough considered to be related to masses in close contact to the trachea and to gastropharyngeal reflux.

Acknowledgements The authors would like to thank Dr. Armelle Schuller (Department of Pneumology, Centre Hospitalier Universitaire de Strasbourg, France) for the clinical care of the patient.

Contributors NC and VC were involved in the conception and design of article. NC prepared the figures and was involved in the data extraction and data entry. DJ, PC and VC were involved in the data analysis. All authors edited and revised manuscript and approved the final version of manuscript.

Disclaimer The authors certify that the manuscript has not been published previously and that it is not under consideration for publication elsewhere. All authors are in agreement with the content of the manuscript. All funding sources, financial conflicts and acknowledgements have been reported in the manuscript.

Competing interests None declared.
Patient consent Obtained.

Provenance and peer review Not commissioned; externally peer reviewed.

(C) BMJ Publishing Group Ltd (unless otherwise stated in the text of the article) 2017. All rights reserved. No commercial use is permitted unless otherwise expressly granted.

\section{REFERENCES}

1 Hirbe AC, Gutmann DH. Neurofibromatosis type 1: a multidisciplinary approach to care. Lancet Neurol 2014;13:834-43.

2 Zamora AC, Collard HR, Wolters PJ, et al. Neurofibromatosis-associated lung disease: a case series and literature review. Eur Respir I 2007;29:210-4.

3 Ueda K, Honda O, Satoh Y, et al. Computed tomography (CT) findings in 88 neurofibromatosis 1 (NF1) patients: prevalence rates and correlations of thoracic findings. Eur J Radiol 2015;84:1191-5.

Copyright 2017 BMJ Publishing Group. All rights reserved. For permission to reuse any of this content visit http://group.bmj.com/group/rights-licensing/permissions.

BMJ Case Report Fellows may re-use this article for personal use and teaching without any further permission.

Become a Fellow of BMJ Case Reports today and you can:

- Submit as many cases as you like

- Enjoy fast sympathetic peer review and rapid publication of accepted articles

Access all the published articles

- Re-use any of the published material for personal use and teaching without further permission

For information on Institutional Fellowships contact consortiasales@bmjgroup.com

Visit casereports.bmj.com for more articles like this and to become a Fellow 